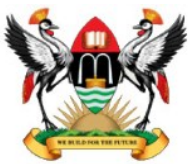

East African School of

Higher Education Studies \& Development
Makerere Journal of Higher Education

ISSN: $1816-6822 ; 9$ (1) (2017) $103-112$

DOI: http://dx.doi.org/10.4314/majohe.v9i1.9

(C) The Author(s) 2017

Reprints \& permission: EASHESD

http://ajol.info/majohe

\title{
Stress Level and Academic Performance of University Students in Kwara State, Nigeria
}

\author{
Oduwaiye Rhoda Olape ${ }^{1,}{ }^{*}$, Yahaya Lasiele A. ${ }^{1}$, Amadi Esther Chiaka ${ }^{1}$, Tiamiyu \\ Kamoru Abidoye ${ }^{2}$ \\ ${ }^{1}$ University of Ilorin [*Corresponding author: oduwaiyerhoda@yahoo.co.uk]; ${ }^{2}$ Al-Hikmah \\ University
}

\begin{abstract}
This study examined the relationship between level of stress and students' academic performance in Universities in Kwara State, Nigeria. The study adopted a descriptive survey research design. Proportional stratified random sampling was used to select 300 students for the study. A "Students' Stress Level Questionnaire (SSLQ)" and "Students' Academic Performance proforma (SAPP)" was used to collect data. The instruments were validated by experts in educational management and counselling and a test-re-test reliability procedure was used to determine their reliability. Descriptive statistics were used to answer the research questions while Pearson product-moment correlation statistic was used to test the research hypotheses stated. The findings were that a significant relationship exists between the stress level and academic performance of the students. There is also a significant relationship between level of personal stress, interpersonal stress, environmental stress, achievement stress and academic performance. Therefore, it was recommended that the universities organize stress management seminars and workshops in collaboration with the Counselling and Human Development department. It is also recommended that university administrators make the learning environment conducive to boost academic performance and reduce stress.
\end{abstract}

Keywords: Stress; Academic performance; Student affairs.

\section{$1 \quad$ Introduction}

The increasing awareness of the existence of stress and its adverse effects on Nigerian citizens has aroused the interest of professional bodies and educationists. Stress has been identified as a problem in many work places which leads to absenteeism, low morale and poor academic performance among students. Stress is a state of tension that occurs when there are demands and 
pressures that task an individual's ability to adjust. Although higher education is often regarded as a period of fun and few responsibilities, the reality is that learning in higher institutions in Nigeria can be very stressful. Among students, stress results from the challenge of adjusting to transactions in change. For instance, resumption and vacation from school and returning to school or staying home after breaks may cause stress as students adapt to changes in routine. The fact remains that tertiary education students need to adjust to the demands of living more independent without the assistance of parents or families in managing their time (Hayble, 2002).

Tertiary education has become increasingly complex, the students are faced with more academic programmes which are to be covered within a short period. Stress can create positive or negative feelings. When effectively handled, stress can help to compel one to greater action which can lead to higher achievement while negative feelings can lead to some health related problems, such as headache, stomach upset, insomnia, high blood pressure and even stroke (Shield, 1995).

Stressors in this study are the challenges encountered by university students which are perceived to generate stress. Stress level is the extent to which students experience tensions, worries, pressures and anxiety in the process of pursuing their academic activities in the universities.

\subsection{Related Literature}

The phenomenon of stress continues to receive increasing attention from various fields such as medicine, counselling, psychologists and educational managers. Different researchers have defined stress in different ways. Dwyer and Cumming (2001) described stress as the demands made on people to which they respond and which affect their physical, psychological and behavioural characteristics, while Oniye (2001) viewed it from a psychological and physiological perspectives. Students react to higher education in various ways. To some students, higher education is stressful because it is an abrupt change from secondary school level. Students in higher educational institutions are viewed as leaders of tomorrow. They have academic success as their major goal. For this goal to be achieved, it requires dedication, sacrifice, selfdiscipline, motivation and cordial relationship between students and lecturers. Students at this level are saddled with a lot of responsibilities and challenges (Imonikebe, 2009) which may sometimes result in stress. To some, even separation from home is a source of stress.

Stress touches almost every segment of life. It can be seen as a major contributor to sickness. It is dangerous to both mental and physical health and can lead to a total breakdown of an individual's system. Stress is known to be causative agents to some dominant psychological problems such as loss of 
appetite, memory loss, absent-mindedness, depression, frustration, nervousness and blood pressure which are common in Nigeria (Adewole, 2006). The daily hazard experienced by Nigerian students has been aggravated by the present situation of the country which includes, insensitivity to the plight of these hazard by the government, instability in government, strikes, frequent changes in government policies, transportation problem and government inability to maintain law and order leading to insecurity of lives and properties (Oladimeji, 2007).

Vermut and Steensman (2005), Malachpines and Keinan (2007) also defined stress as discrepancy between environmental demands (stressors) and individual capacities to fulfil the demands. Also, Campbell (2006) described stress as the adverse reaction people have to excessive pressure or other types of demands placed on them. It occurs when an individual is confronted by a situation that they perceive as overwhelming and cannot cope with.

Agolla and Ongori (2009) found that most students in the higher institutions of learning are experiencing stress in their daily academic activities. Nakalema and Ssenyonga (2013) observed that for many students, university life is a major transition because they are free to decide what to do without undue influence of their parents. They have a responsibility to struggle to meet the expectations of their parents which include expectations related to their academic performance (Smith \& Renk, 2007).

Researchers such as Woun (2003), Ongori (2007), Erkutlu and Chafra 2006) identified the following as stressors, too many assignments, competition with other students, academic failures, lack of 'pocket money', poor relationship with other students or lecturers, family or problems at home, accommodation and overcrowded lecture halls. When students are faced with these stressors, they become disorganized, disoriented and find it extremely difficult to cope. However, majority of students claimed that course load is the source of the stress which in turn affects their Grade Point Average (Talib and Zai-urRehman, 2012). Also some students report that the prospect of having to sit for examinations is stressful because of the pressure to revise all the learned material within a given period of time (Mani, 2010). Baldwin, Wilkinson and Bradley (2009) emphasized that student-workers experience greater stress during mid-term and final examination periods of the academic year than during any other time. This arises from absenteeism from class due to the demand to be at work. Malach-Pines and Keinan (2007), Ongori (2007) Ongori and Agolla (2009) identified stress symptoms as lack of energy, taking over the counter medication, high blood pressure, feeling depressed, increase in appetite, restlessness, tensions and anxieties among others. They discovered that the major causes of stress among students are academic workload, inadequate resources, low motivation and poor performance in academic work, overcrowded lecture halls and uncertainty of getting jobs after graduation from the 
university. It was discovered by Macan, Shahani, Dipboye and Philips (1990), Baldwin, Wilkinson and Barkley (2000) and Robetham (2008) that coping strategies be used by students when experiencing academic stress. Some resort to avoidant coping, drug abuse, denial and behavioural disengagement while others cope actively through acceptance, planning and positively reframing and taking the necessary steps to overcome the academic stress. Other forms of coping mechanisms used by students include sports, music, hanging out with friends, sleeping (Shaikh, 2004).

\subsection{Purpose of the Study}

The main purpose of this study is to investigate relationship between level of stress experienced by students in Universities in Kwara State and their academic performance. The study also examines the influence of different types of stress on the respondents' academic performance. Specifically, the purpose of the study is to:

1. examine the level of stress among university students in Kwara State; and

2. examine the sources of stress among students of universities in Kwara State.

\subsection{Research Questions}

The following research questions were raised to guide the study.

1. What is level of stress among University students in Kwara State?

2. What is the level of academic performance of University students in Kwara State?

\section{$1.4 \quad$ Research Hypotheses}

The following null hypotheses were tested:

$\mathrm{HO}_{1}$ There is no significant relationship between level of stress and academic performance of University students in Kwara State, Nigeria.

$\mathrm{HO}_{2}$ There is no significant relationship between level of personal stress and academic performance of University students in Kwara State, Nigeria.

$\mathrm{HO}_{3}$ There is no significant relationship between level of environmental stress and academic performance of University students in Kwara State, Nigeria.

$\mathrm{HO}_{4}$ There is no significant relationship between level of achievement stress and academic performance of University students in Kwara State, Nigeria. 


\section{$2 \quad$ Methodology}

The research design employed in this study is descriptive survey. The population of this study consists of all the University students in Kwara State. There are four universities in Kwara State, Nigeria, namely, University of Ilorin, Kwara State University Malete, Al-Hikmah University Adewole, Ilorin and Landmark University, Omu Aran. They are federal, state and private universities respectively. The target population was 300 level students in the selected Universities. The decision to choose 300 level students was due to the fact that they have gone through series of academic stress and rigours as they are nearing point of graduation.

Proportional sampling technique was used to select the respondents. Thus 141 respondents were selected from University of Ilorin, 99 from Kwara State University Malete, 24 from Al-Hikmah University, Ilorin and 36 from Landmark University Omu Aran.

Two research instruments titled "Students' Stress Level Questionnaire" (SSLQ) and "Students Academic Performance Proforma" (SAPP) were used to obtain relevant data from the respondents. The instruments were validated using content validity. The test-re-test reliability procedure was used to determine the reliability of the instrument Pearson product-moment correlation statistic was used to determine the co-efficient of the instruments and this yielded 0.64 and 0.87 respectively. In analysing the data, descriptive statistics, rank order and Pearson product-moment statistic were used to test the hypotheses at 0.05 level of significance.

\section{$3 \quad$ Results and Discussion}

\subsection{Level of stress among University students}

The findings on the level of stress among the students are summarized in Table 1.

Table 1: Level of stress among university students

\begin{tabular}{lll}
\hline Stress Level & Frequency & $\%$ \\
\hline High & 284 & 94.7 \\
Low & 16 & 5.3 \\
Total & 300 & 100 \\
\hline
\end{tabular}

Out of the 300 respondents, 284 (94.7\%) experienced high level of stress, while 16 (5.3\%) experienced low level of stress. A high level of stress may disturb or thwart the effort of a person from reaching or achieving his goal (Oladipupo, 
2007). High level of stress can lead to poor academic performance, examination malpractice and fear of failure (Abdulahi, 1999).

\subsection{Students' Academic Performance}

The findings on the students' level of Academic Performance of are shown in Table 2.

Table 2: Distribution of students by performance

\begin{tabular}{llllllll}
\hline Grade Point & Ilorin & KWASU & Al-Hikmah & Landmark & Total & $\%$ & Academic Level \\
\hline $5.00-4.50$ & 3 & 3 & 0 & 0 & 6 & 21 & High \\
$4.49-3.50$ & 33 & 18 & 1 & 6 & 58 & & \\
$3.49-2.50$ & 90 & 34 & 3 & 4 & 131 & 44 & Moderate \\
$2.49-1.50$ & 66 & 37 & 0 & 2 & 105 & & \\
$1.49-1.00$ & 0 & 0 & 0 & 0 & 0 & 35 & Low \\
Total & 192 & 92 & 4 & 12 & 300 & 100 & \\
\hline
\end{tabular}

Table 2 shows the level of academic performance of University students in Kwara State. The result shows that students from the universities with grade points between 5.00-3.50 can be said to have attained a high academic level of performance and this is $21 \%$ of the respondents. Students who have grade points between 3.49-2.50 are classified to have moderate academic performance and this is $44 \%$ of the respondents. A total of $105(35 \%)$ of the respondents attain low academic level of performance. The result shows that despite the high level of stress among students (respondents) as shown in table 1, quite a number of the students still maintain a moderate academic performance. This means that the students are managing their stress effectively.

\subsection{Testing of Hypotheses}

$H O_{1}$ : There is no significant relationship between level of stress and academic performance of University students in Kwara State, Nigeria.

Table 3: Level of stress and Academic Performance

\begin{tabular}{llllllll}
\hline Variable & No. & Mean & SD & df & Cal. $r$ & Critical r & Decision \\
\hline Stress Level & 300 & 54.46 & 6.30 & 298 & $0.32^{*}$ & 0.19 & HO rejected \\
& & & & & & & \\
Academic Performance & 300 & 13.91 & 2.89 & & & & \\
\hline
\end{tabular}

* Significant $<0.05$

Table 3 shows the result of correlation analysis of level of stress and academic performance of University students in Kwara State. The calculated $r$ of 0.32 is 
greater than the critical $r$ of 0.19 at 0.05 level of significance. Hence, the null hypothesis is rejected. This implies that stress has a significant relationship with academic performance of university students in Kwara State, Nigeria. Stressful conditions like inability to pay school fees, meet deadlines in submitting assignments, inability to comprehend what has been taught, unemployment after school, power failure and inadequate financial support are all sources of stress which can affect academic performance (Erkutlu and Chafra 2006).

$\mathrm{HO}_{2}$ : There is no significant relationship between level of personal stress and academic performance of university students in Kwara State, Nigeria.

Table 4: Level of Personal Stress and Academic Performance

\begin{tabular}{llllllll}
\hline Variable & No. & Mean & SD & df & Cal. $r$ & Critical $r$ & Decision \\
\hline Personal stress & 300 & 17.41 & 2.67 & 298 & $0.27^{*}$ & 0.19 & HO rejected \\
& & & & & & & \\
Academic Performance & 300 & 13.91 & 2.89 & & & & \\
\hline
\end{tabular}

* Significant $<0.05$

Table 4 shows that correlation analysis of the level of personal stress and academic performance of University students in Kwara State. The calculate $r$ of 0.27 is greater than the critical $r$ of 0.19 at 0.05 level of significance. Hence the null hypothesis is rejected. Alao (2003) confirmed that pressures and worries within an individual such as sickness, inability to do things by oneself and financial problem are personal stress that affects academic performance.

$\mathrm{HO}_{3}$ : There is no significant relationship between level of environmental stress and academic performance of university students in Kwara State, Nigeria.

Table 5: Level of Environmental Stress and Academic Performance

\begin{tabular}{llllllll}
\hline Variable & No. & Mean & SD & df & Cal. r & Critical r & Decision \\
\hline $\begin{array}{l}\text { Environmental } \\
\text { Stress }\end{array}$ & 300 & 13.29 & 2.65 & & & & \\
$\begin{array}{l}\text { Academic } \\
\text { Performance }\end{array}$ & 300 & 13.91 & 2.89 & & & & HO rejected \\
\hline
\end{tabular}

* Significant $<0.05$

As shown in Table 5, the calculated $r$ of 0.23 is greater than the critical $r$ of 0.19 at 0.05 level of significance. The null hypothesis is therefore rejected. This implies that there is a relationship between level of environmental stress and academic performance of university students in Kwara State. The university surroundings contribute in a large extent to level of stress. Environmental stress 
is a form of discomfort experienced within the area an individual lives or studies. Dirty environment, noise, water and air pollution, traffic congestion or unavailability of proper transport system are sources of environmental stress. When these are prevalent on university campus they can affect academic performance.

$\mathrm{HO}_{4}$ : There is no significant relationship between level of achievement stress and academic performance of university students in Kwara State, Nigeria.

Table 6: Level of Achievement stress and Academic Performance

\begin{tabular}{llllllll}
\hline Variable & No. & Mean & SD & df & Cal. r & Critical r & Decision \\
\hline Achievement Stress & 300 & 14.67 & 2.88 & 298 & $0.49 *$ & 0.19 & HO rejected \\
& & & & & & & \\
Academic Performance & 300 & 13.91 & 2.89 & & & & \\
\hline * Significant $<0.05$ & & & & & & &
\end{tabular}

As shown in table 6 , the calculated $r$ of 0.49 is greater than the critical $r$ of 0.19 at 0.05 level of significance. The null hypothesis is therefore rejected. This implies that there is a relationship between level of achievement stress and academic performance of university students in Kwara State. According to Chafra (2006) Awino and Agolla (2008) academic stress such as too many assignments, academic failures, overcrowded classrooms and even poor relationship with other students could influence academic achievement as these stressors usually lower students' Grade Point Averages. A good student whose Grade Point is likely to be 4.50-5.00 may drop to 3.50 or even below. Achievement stress is the wide spread "invisible disability", it is rarely detected but generally get worse as students progress through school activities.

\section{Conclusion and Recommendations}

The study has shown that a significant relationship exist between stress level and academic performance of university students in Kwara State. The university students in Kwara State have moderate academic performance as a result of high influence of stress personally, in their environment and also in their achievement, which manifest in the achievement of their academic goal. The ultimate goal of any institution is to graduate students who would be useful to themselves and contribute meaningfully to the socio-economic development of their society through adequate learning and character development. This goal can only be achieved through concerted efforts of students, staff and the university administration to reduce the level of stress experienced by the 
students to its barest minimum. Based on the findings of the study, the following recommendations are made.

1. Orientation programmes, seminars and workshops should be organized by the universities in collaboration with the counselling and human development centres to enlighten the students on the stressor that they are likely to experience in the course of their academic pursuit. Effect of these stressors on the students should be emphasized.

2. There should be an increased government involvement in initiating effective programmes that could improve academic achievement like good libraries including e-learning centres. Internet facilities should be made available at anywhere on campus. University administrators should make learning environment conducive by providing necessary infrastructures like good toilets, enough and always available transport system, good hostel accommodation and regular water supply and electricity.

3. Academic planning office should concentrate on appropriate school calendar so that academic programmes are not choking especially semester examinations. Examination halls should be well-spaced to avoid overcrowdedness which can aid examination malpractice.

4. Administrators at all levels should introduce coping strategies which would help students to overcome whatever stress they might experience. As ability to cope with this stress is what will help them to achieve success in their academics.

\section{References}

Abdulahi, O.E. (1999). Influence of sex, level of study and religious belief on the perception of stress among Nigerian undergraduate students. Journal of School Health Education, 6(1\&2), 48-57.

Agolla, J.E. \& Ongori, H. (2009). An assessment of academic stress among undergraduate students. The case of University of Botswana, Gaborone. Educational Research Review, 4 (2) retrieved at http.www.academicjournals.org/ERR.

Baldwin, D.A.; Wilkinson, F.C. \& Barkley, D.C. (2009). Effective management of student employment: organizing for standard deployment in academic libraries. Englewood: Libraries unlimited, Inc.

Erkutlu, H.V. \& Chatra, J. (2006). Relationship between leadership power bases and job stress of subordinates: example from boutique hotels, Management Resources, News 29(5):285-297.

Hayward, S. (1998). Stress, health and psychoneuro immunology. Psychological View, 5(1), 16-19. 
Macan, T.H.; Shahani, C.; Dipboye, R.L. \& Philips, A.P. (1990). College students time management: correlations with academic performance and stress. Uganda. Journal of educational psychology (82), 760-768.

Malach-Pines, A. \& Keinan, G. (2007). Stress and burnout in Israel Police Officers during Palestinian uprising. International Journal of stress management.

Mani, V. (2010). Students' perception of the impact of coursework on exam stress. Uganda. International Journal of Arts and Sciences (3) 104-110.

Nakalema, G. \& Ssenyonga, J. (2013). Academic stress: Its causes and results at a Ugandan University, Uganda. African Journal of Teacher Education (AJOTE) 3(3).

Oladimeji, M.O. (2002). Stressor and stress management among secondary school teachers in Ilorin West Local Government Area of Kwara State. Unpublished M.Ed. thesis, University of Ilorin.

Ongori, H. (2007). A review of literature on employee turnovers. Gaborone. African Journal of Business Management (1)3:49-54

Oniye, D.A. (2001). A cross-ethnic study of stress levels, support system and adjustment strategies among widows in Nigeria. Network of Psychological Studies of Women Issues, Department of Psychology, University of Ibadan.

Shaikh, B.T.; Kahloon, A.; Kazmi, M. (2004). Students stress and coping strategies: A case of Pakistani medical school. Education for Health, 17, 346-353.

Shield, N. (1995). Finding from a little 111 study of students' satisfaction on the UM-St. Louise Campus, unpublished raw data.

Smith, A. \& Renk, O.A. (2007). Predictors of academic related stress in college students: an examination of coping, social support, parenting and anxiety. Journal of National Association of Student Personnel Administrators (NASPA) 44:405-431.

Talib, N. \& Zair-ur-Rehman, M. (2012). Academic performance and perceived stress among university students. Uganda. Educational Research Review (7) $127-132$.

Vermut, O. \& Steensma, R. (2005). How can justice be used to manage stress in organizations. In J. Greenberg and J.A. Colquitt (Ed). Handbook of Organisational Justice. 